\title{
MEMAHAMI DIKOTOMI DAN DUALISME PENDIDIKAN DI INDONESIA
}

\author{
E. Kurniyati \\ etykurniyati63@gmail.com \\ (Dosen Fakultas Agama Islam, Universitas Muhammadiyah Tangerang)
}

\begin{abstract}
Abstrak:
Pengdikotomian pendidikan di Indonesia terjadi disebabkan oleh banyak hal. Pertama, dikotomi merupakan warisan zaman koloni, yaitu para penjajah memberikan kebebasan dalam beragama, tapi mereka setengah-setengah memberikan kebebasan. hal ini terbukti misalnya pemberian kebebasan menempuh pendidikan hanya dibatasi pada anak bangsawan. Kedua, Setelah kemerdekaan, dulaisme yang diwariskan pemerintah kolonial Belanda tetap mengakar dalam dunia pendidikan. Pandangan beberapa pejabat yang menangani bidang pendidikan yang kurang menghargai sekolah-sekolah Islam mendorong sebagian pemimpin dan pengelola sekolah tersebut berpegang pada sikap semula: berdiri di kutub yang berbeda dengan sekolah Umum. Ketiga, kondisi riil dalam Negara, yakni adanya persoalan politis antara para pemegang kekuasaan.
\end{abstract}

\section{Kata Kunci: Dikotomi, Dualisme, Pendidikan.}

\section{A. Pendahuluan}

Dalam Rencana Strategis (Renstra) Departemen Pendidikan Nasional 20052009 yang diajukan ke Dewan Perwakilan Rakyat (DPR), muncul dikotomi baru, yang membedakan pendidikan formal mandiri dan formal standar atas dasar kemampuan ekonomi dan akademis (Kompas, 6/4/2005). Pendidikan formal mandiri merepresentasi pendidikan bagi masyarakat berkemampuan ekonomi, pendidikan elite, mahal, bermutu, dan menjadi tempat anakanak yang memiliki kemampuan akademis tinggi. Sebaliknya, pendidikan formal standar merepresentasi pendidikan "biasa saja", tempat berkumpulnya anak-anak

\footnotetext{
${ }^{1}$ Ada dua faktor yang melandasi perumusan dikotomi pendidikan formal mandiri vs formal standar itu. Pertama, keterbatasan kemampuan pemerintah menyediakan anggaran pendidikan. Sehingga, masyarakat yang mampu secara ekonomi, yang memandang pendidikan sebagai investasi ekonomi, perlu dimobilisasi melalui jalur pendidikan formal mandiri untuk menanggung biaya pendidikan sendiri. Sedangkan, masyarakat miskin yang tidak mampu berinvestasi disediakan jalur pendidikan formal standar yang biaya
}

yang tidak memiliki kemampuan akademis, miskin, dan disubsidi pemerintah. ${ }^{1}$ Kebijakan dikotomi pendidikan formal mandiri dan formal standar itu tampaknya tidak akan menjadi masalah bagi masyarakat lapis menengah ke atas. Selain akibat aneka kebijakan pemerintah, aspirasi masyarakat, terutama lapis menengah ke atas juga cenderung menumbuhkan dikotomi-dikotomi itu selaras dengan kian berkembangnya sistem budaya kapitalistik di masyarakat.

Fenomena di atas hanya merupakan salah satu bentuk dikotomik dalam sistem pendidikan di Indonesia. Masih terdapat banyak dikotomi, atau mungkin politomik,

pendidikannya ditanggung pemerintah bersumber dari APBN. Kedua, kenyataan 30 persen siswa (menurut Richard Felder) berkemampuan akademis tinggi, dirasa perlu mendapat perhatian khusus untuk masuk universitas. Selain memberi akses bagi anakanak dari keluarga mampu secara ekonomi, pendidikan formal mandiri dimaksudkan memberi layanan kelompok anak yang memiliki kemampuan akademis itu. Dengan demikian, mereka yang memiliki kemampuan akademis tetapi berasal dari keluarga miskin akan mendapat "kemudahan akses". 
yang hidup dan me"lembaga" (menjadi fakta sosial) di kalangan masyarakat dan pemerintah Indonesia. Pertama, dari segi ciri keilmuan, terdapat dikotomi antara sekolah dan pesantren, antara sekolah dan madrasah, serta antara Perguruan Tinggi (PT) Umum dan PT agama (Islam). Kedua, dari segi penyelenggara dan pengelola, terdapat sekolah dan PT "miliki" Departemen Pendidikan Nasional, "milik" Departemen Agama, atau lainnya. Ketiga, dari sekolah prestasi dan animo pendaftar, terdapat dikotomi antara sekolah unggulan dan sekolah non-unggulan, serta antara PT unggulan dan PT non-unggulan. Keempat, dari segi pemenuhan Standar Nasional Pendidikan (SNP), terdapat sekolah yang terakreditasi dan tidak terakreditasi, serta antara PT terakreditasi dan PT tidak terakreditasi. Kelima, dari segi keilmuan dan skill terdapat dikotomi antara sekolah menangah umum (SMU) dan sekolah menengah kejuruan (SMK). Keenam, dari segi pengelola dan sumber pendanaan, terdapat dikotomi antara sekolah negeri dan sekolah swasta, dan antara PT Negeri dan PT Swasta.

Secara faktual, politomik tersebut, diakui atau tidak, merupakan fakta sosial yang belum terantitesiskan. Ia telah berjalin kelin dan berakar kuat dalam pandangan sebagian besar masyarakat Indonesia, termasuk para pejabat di berbagai departemen penyelenggara pendidikan di Indonesia, seperti di Departemen Pendidikan Nasional, Departemen Agama, dan Departemen-Departemen lainnya yang menyelenggarakan sekolah kedinasan. Karena kuatnya pandangan dikotomik pada sebagian besar masyarakat, termasuk para pejabat, tersebut maka usaha untuk melakukan konvergensi dan integrasi terhadap semua bentuk politomik tersebut seakan-akan tidak menemukan jalannya, atau bahkan dianggap mustahil untuk melakukannya.
Sebagaimana disebutkan bahwa dalam Undang-Undang Dasar 1945, pasal 33 ayat (3) disebutkan bahwa Pemerintah mengusahakan dan menyelenggarakan satu sistem pendidikan nasional yang meningkatkan keimanan dan ketakwaaan. Ini berarti bahwa pemerintah hanya menyelenggarakan satu sistem pendidikan nasional. Namun, Di sisi lain, Pemerintah pun menyelenggarakan dua bentuk sistem pendidikan, yakni 1) sistem pendidikan yang berorientasi pada pendidikan keilmuan dan skill yang berbasis "sekuler", yakni sekolah, dan 2) sistem pendidikan yang mempertahankan pendidikan agama sebagai ciri khasnya, yakni madrasah. Kedua bentuk pendidikan ini diselenggarakan dan dikelola oleh pemerintah. Secara simplistis keduanya dilabeli dengan "Negeri"; pada tingkat dasar terdapat SDN dan MIN; pada tingkat SLTP terdapat SMPN dan MTsN; pada tingkat SLTA terdapat SMUN, SMKN, dan MAN; sedangkan di tingkat Pendidikan Tinggi terdapat PTUN dan PTAIN. Satu hal yang masih juga dapat diamati sekarang adalah adanya dualitas sistem pendidikan, yakni satu sisi sistem pendidikan yang diselenggarakan dan dikelola oleh pemerintah, dan di sisi lain terdapat sistem pendidikan yang dikelola oleh masyarakat. Dari sudut ini, dualitas terjadi dan terkutubkan menjadi sekolah Negeri dan sekolah Swasta.

Secara formal, pemerintah menyelenggarakan pendidikan formal melalui Departemen Pendidakan dan Kebudayaan (Depdikbud) atau kini dikenal dengan Departeman Pendidikan Nasional (Depdiknas). Satu sisi semua otoritas penyelenggaraan dan pengelolaan pendidikan berada di Depdiknas ini, tetapi pada realitasnya Departemen Agama pun (dan beberapa departemen lainnya) mengelola institusi pendidikan yang berada di bawah naungannya, yakni madrasah (mulai dari madrasah Ibtidaiyah hingga 
Aliyah) dan PTAI. Dengan demikian, pemerintah pada realitasnya telah menerapkan dualisme sistem pendidikan atau sistem pendidikan yang dikotomik.

Dualitas atau dikotomi sistem pendidikan di Indonesia ini terus berlangsung sejak Indonesia merdeka hingga masa reformasi kini (2009). Beberapa pemegang kebijakan dalam pendidikan, dengan berbagai latar dan alasan, masih menajamkan dikotomi ini, dari sejak poiltik kebijakan hingga aspek teknis-operasional. Oleh karena itu, upaya konvergensi sistem, corak keilmuan, dan teknis-operasional harus terus diupayakan agar dikotomi dengan berbagai konsekuensinya dapat diminimalisir. Terlebih, di tengah-tengah krisis multidimensi yang melanda Indonesia, yang salah satunya disebabkan oleh adanya kelemahan dalam sistem pendidikan, upaya intensif konvergensi dan reformasi pendidikan harus terus utamakan. Semua realitas dikotomik dalam sistem pendidikan di Indoneisa tersebut merupakan tantangan bagi para pemikir dan praktisi pendidikan. Diperlukan sejumlah kajian dan penelitian mendalam dan applicable yang mampu mengarah dan mendukung berbagai kebijakan untuk melakukan konvergensi dan integrasi sistem pendidikan di Indonesia tersebut. Oleh karena itu, tulisan ini dimaksudkan untuk memberikan kontribusi solutif bagi hal tersebut. Namun dari semua dikotomi di atas, yang menjadi fokus tulisan ini adalah dikotomi pertama. Persoalan dikotomi pertama akan diberi tekanan, sekalipun pembahasannya nanti akan berimbas pada dikotomi-dikotomi lainya sebagai konsekuensi dari adanya dikotomi pertama tersebut.

Dikotomi yang terus aktual dipolemikkan adalah dikotomi antara ilmu "umum" dan ilmu "agama". Dari dikotomi

${ }^{2}$ John M. Echols dan Hassan Shadily, "dichotomy", Kamus Inggris-Indonesia (Jakarta: PT. Gramedia Utama, 1992), hlm. 180. ini muncullah dua sistem pendidikan di Indonesia, yakni institusi pendidikan umum (sekolah dan PTU) dan institusi pendidikan agama (madrasah, pesantren, dan PTAI). Dikotomi ini telah juga menimbulkan sejumlah kesenjangan dalam pemerataan pendidikan, beserta segala dampak yang dihasilkannya. Pada dasarnya, dikotomi jenis ini, yakni dikotomi dari segi corak keilmuan yang diajarkan di pendidikan formal, telah berurat akar pada sejarah pendidikan di Indonesia sejak masa Nusantara dikuasai oleh kerajaan-kerajaan lokal, masa penjajahan Belanda dan Jepang, hingga tiga masa orde Indonesia merdeka (orde lama, orde baru, dan orde reformasi). Hal ini karena sistem pendidikan yang diimplementasikan oleh pemerintah dan rakyat Indonesia sekarang, diakui atau tidak, masih terkait dengan sistem pendidikan yang dijalankan pada masa Pemerintahan Belanda ketika masih menjajah Negara Kesatuan Republik Indonesia (NKRI) ini.

\section{B. Pengertian Dikotomi dan dulaisme \\ 1. Pengertian Dikotomi}

Dikotomi dalam bahasa Inggris adalah dichotomy adalah pembagian dua bagian, pembelahan dua, bercabang dua bagian. ${ }^{2}$ Ada juga yang mendefinisikan dikotomi sebagai pembagian di dua kelompok yang saling bertentangan. ${ }^{3}$ Secara terminologis, dikotomi dipahami sebagai pemisahan antara ilmu dan agama yang kemudian berkembang menjadi fenomena dikotomik-dikotomik lainnya, seperti dikotomi ulama dan intelektual, dikotomi dalam dunia pendidikan Islam dan

\footnotetext{
${ }^{3}$ Departemen Pendidikan dan Kebudayaan, "dikotomi", Kamus Besar Bahasa Indonesia (Jakarta: Balai Pustaka, 1989), hlm. 205.
} 
bahkan dikotomi dalam diri muslim itu sendiri (split personality). ${ }^{4}$

Bagi al-Faruqi, dikotomi adalah dulaisme religius dan kultural. ${ }^{5}$ Meskipun dikotomi ini adalah problem kontemporer namun keberadaannya tentu tidak lepas dari proses historisitas yang panjang sehingga bisa muncul sekarang ini. Proses sejarah tersebut diawali perkembangan pertemuan Islam-Arab dengan budaya lainnya, yang kemudian dilanjutkan dengan perkembangan lembaga-lembaga pendidikan dalam Islam serta diakhiri dengan pertentangan dua cara berpikir yang cukup berpengaruh dalam pembentukan dikotomi ilmu dalam sejarah peradaban Islam.

Dengan pemaknaan dikotomi di atas, maka dikotomi pendidikan Islam adalah dulaisme sistem pendidikan antara pendidikan agama Islam dan pendidikan umum yang memisahkan kesadaran keagamaan dan ilmu pengetahuan. Dulaisme ini, bukan hanya pada dataran pemilahan tetapi masuk pada wilayah pemisahan, dalam operasionalnya pemisahan mata pelajaran umum dengan mata pelajaran agama, sekolah umum dan madrasah, yang pengelolaannya memiliki kebijakan masing-masing. Sistem pendidikan yang dikotomik pada pendidikan Islam akan menyebabkan pecahnya peradaban Islam dan akan menafikan peradaban Islam yang kqffah (menyeluruh).

\section{Pengertian Dulaisme}

Perkataan "dulaisme" adalah gabungan dua perkataan dalam bahasa latin yaitu "dualis" atau "duo" dan "ismus" atau

${ }^{4}$ Ahmad Watik Pratiknya, "Identifikasi Masalah Pendidikan Agama Islam di Indonesia", Muslih Usa (Ed. ), Pendidikan Islam di Indonesia Antara Cita dan Fakta(Yogyakarta: Tiara Wacana, 1991), hlm. 104. "isme". "Duo" memberi arti kata dua. Sedangkan "ismus" berfungsi membentuk kata nama bagi satu kata kerja. Dulaisme adalah dua prinsip yang saling bertentangan. Secara terminologi dulaisme dapat diartikan sebagai dua prinsip atau paham yang berbeda dan saling bertentangan. Oleh karena itu, dulaisme ialah keadaan yang menjadi dua, dan ia adalah satu sistem atau teori yang berdasarkan kepada dua prinsip yang menyatakan bahwa ada dua substansi.

Asal dualisme ini pada hakikatnya merupakan doktrin filsafat dan metafisika yang lahir dari alam pikiran para filosof Barat dalam melihat entitas jiwa dan raga manusia. Asal usul konsep dulaisme terkandung dalam pandangan hidup tentang alam (world view), serta nilai-nilai yang membentuk budaya dan peradaban Barat. Gagasan tentang dulaisme sebenarnya dapat ditelusuri sejak zaman Plato dan Aristoteles yang memiliki pandangan berhubungan dengan eksistensi jiwa yang terkait dengan kecerdasan dan kebijakan. Plato dan Aristoteles berpendapat bahwa "kecerdasan" seseorang merupakan bagian dari pikiran atau jiwa yang tidak bisa diidentifikasi atau dijelaskan dengan fisik. Jadi dalam pandangan tentang hubungan antara jiwa dan raga, fenomena mental adalah entitas non-fisik dan raga adalah fisik. Oleh karena itu, faham dulaisme ini melihat fakta secara mendua. Akal dan materi adalah dua substansi yang secara ontologis terpisah. Jiwa-raga (mind-body) tidak saling terkait satu sama lain.

Dulaisme yang dikenal secara umum sampai hari ini diterapkan oleh René Descartes (1641), yang berpendapat bahwa pikiran adalah substansi nonfisik. Descartes adalah yang pertama kali memodifikasi

${ }^{5}$ Isma'il Raji a!-Faruqi, Islamization of Knowledge: General Principles and Workplan Hemdon: HIT, 1982), hlm. 37. 
dulaisme dan mengidentifikasi dengan jelas pikiran dengan kesadaran dan membedakannya dengan otak, sebagai tempat kecerdasan. Baginya yang riil itu adalah akal sebagai substansi yang berfikir (substance that think) dan materi sebagai substansi yang menempati ruang (extendedsubstance). Dengan demikian memang secara ideologis diciptakan adanya dulaisme pendidikan, yaitu sekolah umum yang memperoleh sokongan pemerintah dan menjadi tanggung jawab Kementerian Pendidikan Nasional dan madrasah, pondok pesantren, sekolah yang kurang mendapat perhatian dan menjadi tanggung jawab Kementerian Agama.

\section{Dikotomi dan Dualisme Sistem Pendidikan di Indonesia Pra- Kemerdekaan}

Pada saat penjajahan Belanda, satu sisi terdapat institusi pendidikan yang diselenggarakan oleh Pemerintah Hindia Belanda. Hanya $6 \%$ saja penduduk pribumi dapat bersekolah di skolah-sekolah pemerintah Hindia Belanda dan mereka berasal dari kalangan priyayi. Di sisi lain terdapat institusi pendidikan yang diselenggarakan oleh masyarakat (Pesantren dan Madrasah). Bagi masyarakat non-priyayi, mereka mendapatkan pendidikan di pesantren dan madrasah. Karena tekanan politik pemerintah Hindia Belanda, sekolah Islam dan madrasah berada pada kotak dan kubu sendiri.

Husni Rahim berpendapat bahwa "Kebijakan pemerintah Hindia Belanda terhadap pendidikan Islam pada dasarnya bersifat menekan dan membatasi karena kekhawatiran akan munculnya militansi kaum muslimin terpelajar". Wujud kebijakan pemerintah Hindia Belanda yang menekan itu misalnya, tercermin dalam ordonansi guru pada 1905 kemudian diperbarui pada 1926 yang mewajibkan guru-guru agama memiliki surat izin mengajar. Pengalaman penjajahan yang direpotkan perlawanan rakyat di Cilegon pada 1888 yang dikenal sebagai pemberontakan petani Banten, misalnya, dipengaruhi oleh kyai-kyai pesantren dan pemimpin tarekat menjadi pelajaran serius untuk menerbitkan peraturan tersebut. Selain itu juga Ordonansi sekolah liar sejak 1932 yang dimaksudkan untuk mengawasi sekolah swasta yang diselenggarakan orang Indonesia dan Timur asing lainnya. Ia menandaskan bahwa "Kebijakan itulah yang memicu madrasah dan pesantren mengisolir diri dari dunia luar dengan tetap mengajarkan pelajaran agama. Masingmasing institusi pendidikan tersebut mempunyai sistem pendidikan yang secara diameteral berbeda dan dikotomik. A. Murni Kawakib dalam bukunya Pesantren and Globalization. ${ }^{6}$ menggambarkan mengenai dua sistem pendidikan di Indonesia yang berakar sejak jaman kolonial Belanda di Indonesia tersebut. Ia menuliskan:

Within the context of Indonesia history during the Dutch colonial government, there were at least two types of education system in Indonesia, western-style schools or the Dutch educational system and the traditional Islamic education system. The Dutch colonial government offered the first system, that is, the secular or western educational system, which initially aimed at preparation students to work administration staff and professionals in the lowest level of the Dutch government.... The second type of school was the pesantren (Islamic boarding schools), which mainly opted for training in religious education based on the kitab kuning (Arabic classical text).

${ }^{6}$ Kawakib, A. Munir. 2009. Pesantren and Globalization. Malang: UIN Malang Press. hlm. 3-4 
Kutipan A. Murni Kawakib di atas menunjukkan, setidaknya, dua hal. Pertama, dualisme sistem pendidikan formal di Indonesia telah berlangsung sejak jaman kolonial Belanda, yakni satu sisi terdapat sistem pendidikan pemerintah Belanda, dan di sisi lain terdapat sistem pendidikan tradisional Islam (yakn pesantren). Kedua, kedua jenis sistem pendidikan tersebut dibedakan pula dari sudut tujuan. Sekolah Pemerintah Belanda dimaksudkan untuk menghasilkan pekerja administrasi rendah untuk dipekerjakan di Pemerintahan Belanda. Sedangkan Pesantren dimaksudkan sebagai tempat belajar dan latihan bagi para siswa (santrinya) dengan berbasis pada kitab kuning (teks-teks klasik berbahasa Arab). Dalam kategori yang sejalan dengan pesantren ini adalah Meunasah, Rangkang, Dayah, dan Surau. Jika pesantren dianggap identik dengan Jawa, maka Meunasah, Rangkang, dan Dayah identik dengan Aceh, sedangkan Surau identik dengan Sumatra Barat. ${ }^{7}$ Institusi pendidikan lokal Indonesia (pesantren, meunasah, rangkang, dayah, dan surau) pada masa awal islamisasi Nusantra memainkan peran yang cukup banyak. Pertama, menjadi pusat Islamisasi, tempat dimensi institusional (nilai-nilai) Islam disosialisasikan kepada penduduk pribumi, melalui berbagai cara, kegiatan, dan media. Kedua, pemelihara dari nilainilai tradisional Islam; dan ketiga, sebagai pusat pendidikan Islam dan mencetak kader-kader dakwah Islam (da'i dan atau muballigh). ${ }^{8}$

Pada masa selanjutnya, ketika masa penjajahan Hindia Belanda (dan Jepang), institusi-instusi pendidikan Islam tradisional di atas menambah fungsi dan perannya, yakni sebagai pusat perlawanan

${ }^{7}$ Daulay, Haidar Putra. 2007. Sejarah Pertumbuhan dan Pembaruan Pendidikan Islam di Indonesia. Jakarta: Kencana Prenada Media Group. hlm. 23-28 dan resistensi terhadap kolonialisme dan imperialisme (Barat-Kristen). Di sisi lain, institusi pendidikan tradisional ini juga merupakan "lawan" dari institusi pendidikan yang dibangun oleh pemerintah Hindia Belanda dan lainnya. Dalam kiprahnya semua institusi pendidikan yang ada saat itu secara diameteral sangat berbeda dan menghasilkan sistem pendidikan yang berbeda pula.

\section{Evolusi Dikotomi dan Dualisme Sistem Pendidikan Formal Di Indonesia Pasca-Kemerdekaan}

Berdasarkan pada paparan di atas, dikotomi dan dualitas sistem pendidikan di Indonesia tidak dapat dilepaskan dari persoalan sejarah bangsa Indonesia sendiri. Hal ini karena sistem pendidikan yang diterapkan oleh pemerintah sejak masa kemerdekaan hingga sekarang merupakan hasil akumulasi dari pergumulan di antara bangsa ini dengan sejarah dan politik pendidikan sebelumnya dan adaptasi terhadap lingkungan pada setiap zaman dan tempat. Untuk memotret evolusi sistem pendidikan nasional di Indonesia, maka makalah ini akan berusaha untuk menganalisis berbagai produk UndangUndang tentang Sisten Pendidikan Nasional, sejak masa orde baru hingga masa reformasi. Yang dimaksud dengan UndangUndang adalah seperangkat aturan-aturan atau ketentuan yang terpadu dari semua satuan dan kegiatan pendidikan yang berkaitan satu dengan lainnya untuk mengusahakan tercapainya tujuan pendidikan nasional. Undang-undang sendiri dalam hirarki hukum di Indonesia merupakan implementasi dari UndangUndang Dasar (UUD). UUD sendiri merupakan penjabaran dari konstitusi

${ }^{8}$ Azra, Azyumardi. 2005. "Islamic Thought: Theory, Concept, and Doctrines in the Context of Southeast Asia”. Dalam KS Nathan dan HM Kamali. 2005. Islam in Southeats Asia for the 21th Century. Singapore: ISEAS. hlm. 5 
negara (preambul/pembukaan UUD 1945) dan Falsafah Negara (Pancasila).

Sejak masa kemerdekaan hingga masa reformasi telah lahir beberapa Undang-Undang tentang Sistem Pendidikan Nasional ini. Oleh karena itu, makalah ini setidaknya akan menganalisis beberapa di antaranya, yakni 1) Undang-Undang No. 4 tahun 1950 yang kemudian dikukuhkan kembali melalui Ketetapan MPRS No. XXVII/MPRS/1966. 2) Sistem Pendidikan Nasional Pasca dikeluarkannya Surat Keputusan Bersama (SKB) Tiga Menteri tahun 1975; 3) Sistem Pendidikan Nasional versi Undang-Undang No 2 Tahun 1989; dan 4) Sistem Pendidikan Nasional versi Undang-Undang No. 20 Tahun 2003.

\section{Masa Kemerdekaan Awal}

Dalam pembukaan UUD 1945 dinyatakan bahwa salah satu tujuan negera Republik Indonesia adalah mencerdaskan kehidupan bangsa. Untuk mencapai tujuan tersebut maka pemerintah dan rakyat Indonesia berusaha membangun dan mengembangkan pendidikan semaksimal mungkin. Usaha-usaha yang dilakukan dalam mengembangkan pendidikan ini adalah. Usaha awal adalah membentuk Panitia Penyelidik Pendidikan dan Pengajaran (P4) pada tahun 1946 pada masa Menteri Pendidikan P dan Kebudayaan-nya dipimpin oleh Mr. Soewandi. Panitia tersebut dipimpin oleh Ki Hajar Dewantara. Panitian ini bertugas untuk meninjau ulang kembali dasar-dasar, isi, susunan, dan seluruh usaha pendidikan dan pengajaran.

Usaha selanjutnya adalah mengadakan kongres pendidikan di Solo (tahun 1947) dan menghasilkan kepanitian Pembentukan Rencana Undang-Undang Pokok Pendidikan dan Pengajaran, yang diketuai oleh Ki Hajar Dewantoro. Pada tahun 1949 diselenggarakan Kongres Pendidikan kedua di Yogyakarta, yang banyak melahirkan saran dan rekomendasi untuk penyusunan Undang-Undang Pokok Pendidikan. Undang-Undang Pendidikan sendiri kemudian lahir pada tahun 1950 melalui Undang-Undang No. 4 tahun 1950 dengan nama Undang-Undang tentang Dasar Pendidikan dan Pengajaran (UUPP) di sekolah. UUPP ini terdiri dari 17 bab dan 30 pasal. Di dalam UUPP tersebut dicantumkan tujuan dan dasar-dasar pendidikan dan pengajran sebagai berikut:

a. Tujuan Pendidikan, Bab II Pasal 3; "Tujuan pendididikan dan Pengajaran ialah membentuk manusia susila yang cakap dan warga negara yang demokratis serta bertanggung jawab tentang kesejahteraan masyarakat dan tanah air".

b. Dasar Pendidikan dan Pengajaran, Bab III Pasal 4; "Pendidikan dan Pengajaran berdasarkan atas asas-asas yang termasuk dalam Pancasila, UndangUndang Dasar Negara Republik Indonesia dan atas kebudayaan kebangsaan Indonesia.

Dengan berdasar pada UUPP di atas, pendidikan formal yang diselenggarakan oleh pemerintah adalah sekolah (SD, SMP, SMA). Sedangkan institusi pendidikan lainnya hanya merupakan binaan dari pemerintah, sedangkan pengelolanya adalah swasta atau pribadi. Pada masa awal ini, perhatian pemerintah terhadap madrasah atau pendidikan Islam umumnya lebih meningkat, dibanding masa pemerintahan Hindia Belanda Badan Pekerja Komite Indonesia Pusat (BPKIP), misalnya, menerbitkan maklumat tentang perlunya peningkatan pengajaran di madrasah. Pada tanggal 3 Januari 1946 Kementerian Agama resmi berdiri yang antara lain bertugas untuk mengurusi soalsoal yang berkenaan dengan kehidupan beragama bagi seluruh masyarakat Indonesia, termasuk masalah pendidikan agama. Berdasarkan hal tersebut maka Departemen Agama diberikan keleluasaan untuk mengelola institusi pendidikan (madrasah dan pesantren), termasuk bertanggung jawab terhadap pendidikan 
Agama di sekolah-sekolah yang dikelola oleh Departemen Pendidikan Nasional. Menurut Peraturan Menteri Agama Nomor 1 tahun 1946 dan Peraturan Menteri Agama Nomor 7 tahun 1950, yang dimaksud dengan madrasah adalah a) Tempat pendidikan yang diatur sebagai sekolah dan membuat pendidikan dan ilmu pengetahuan agama Islam menjadi pokok pengajarannya, b) Pondok dan pesantren yang memberi pendidikan setingkat dengan madrasah

Sayangnya perhatian itu tak berlanjut dan tampak dari UU Pendidikan Nasional No. 4/1950 jo UU No. 12/1954 yang hanya memasukkan pendidikan agama di sekolah umum, namun soal madrasah dan pesantren tidak dimasukkan sama sekali. Dalam perkembangan selanjutnya, dasar, tujuan, dan isi pendidikan dapat dilihat dalam Ketetapan MPRS No. XXVII/MPRS/1966, yang sebagian isinya adalah sebagai berikut:

a. Dasar Pendidikan Nasional; Dasar Pendidikan Nasional adalah falsafah Negara Pancasila.

b. Tujuan Pendidikan Nasional; Tujuan Pendidikan Nasional ialah Membentuk manusia Pancasilais Sejati berdasarkan ketentuan-ketentuan seperti yang dikehendaki oleh Pembukaan UndangUndang Dasar 1945 dan Isi UndangUndang Dasar 1945.

c. Isi Pendidikan Nasional; Untuk mencapai dasar tujuan di atas, maka isi pendidikan nasional adalah a) Mempertinggi mental-moral budi pekerti dan memperkuat keyakinan agama, b) mempertinggi kecerdasan dan keterampilan, c) Membina dan memperkembangkan fisik yang kuat dan sehat.

Tap MPRS di atas lahir setelah kegagalan G 30 S/PKI yang sekaligus menandai lahirnya Orde Baru. Melalui Tap MPRS tersebut maka penguatan pendidikan
Agama di sekolah umum mendapat perhatian serius. Berdasarkan Tap MPRS maka lahirlah peraturan bersama antara Menteri Agama dan Menteri Pendidikan dan Kebudayaan pada tanggal 23 Oktober 1967. Peraturan bersama tersebut menetapkan pengalokasian waktu untuk pendidikan Agama di sekolah, yakni kelas 1 dan 2 sekolah dasar diberikan mata pelajaran agama selama 2 jam perminggu, kelas 3 diberikan mata pelajaran agama selama 3 jam perminggu, sedangkan kelas 4 sampai kelas 6 diberikan mata pelajaran agama ini selama 4 jam perminggu. Hal ini berlaku pula bagi SMP dan SMA. Sedangkan di PT diberikan selama 2 jam perminggu. ${ }^{9}$

\section{Sistem Pendidikan Nasional versi SKB Tiga Menteri}

Pada tahun 1972 dan tahun 1974, Presiden Soeharto mengeluarkan Keppres No. 34/1972 dan Inpres No. 15/1974 yang dianggap melemahkan dan mengasingkan madrasah dan pendidikan nasional yang memunculkan reaksi keras umat Islam. Untuk meredam reaksi tersebut kemudian muncul Surat Keputusan Bersama (SKB) tiga menteri yakni Menteri Agama, Menteri Pendidikan dan Kebudayaan, dan Menteri Dalam Negeri pada 1975 yang mensejajarkan level madrasah dengan sekolah umum, yakni Madrasah Ibtidaiyah (MI) yang setingkat dengan SD, Madrasah Tsanawiyah (MTs) yang setingkat dengan SMP, dan Madrasah Aliyah (MA) yang setingkat dengan SMA. SKB tiga menteri ini pada hakikanya adalah untuk meningkatkan mutu pendidikan di madrasah. Dalam Surat Keputusan Bersama (SKB) tahun 1975, Bab I Pasal I disebutkan bahwa, "Yang dimaksud dengan madrasah dalam keputusan Bersama ini adalah lembaga Pendidikan yang menjadikan mata pelajaran agama Islam sebagai dasar yang

\footnotetext{
${ }^{9}$ Steenbrink, Karel. 1985. Pesantren, Madrasah, Sekolah. Jakarta: LP3ES. hlm. 94
}

8 | Rausyan Fikr. Vol. 14 No. 1 Maret 2018. ISSN. 1979-0074 e-ISSN. 9772580594187 
diberikan sekurang-kurangnya $30 \%$ di samping mata pelajaran umum".

Dengan terbitnya SKB tiga Menteri tahun 1975 , pada fase ini mata pelajaran umum di madrasah di setiap levelnya lebih banyak, yakni sekitar 70\%. Walaupun demikian, kedudukan mata pelajaran agama tetap memegang peranan yang amat penting seperti tertera dalam kurikulum madrasah aliyah Tahun 1984, sekitar 30\%. Dengan dikeluarkannya SKB Tiga Menteri tersebut, maka madrasah memasuki era baru, yakni era kesetaraan dan kesederajatan antara madrasah dengan sekolah, seperti yang tertera pada bagan di bawah ini.

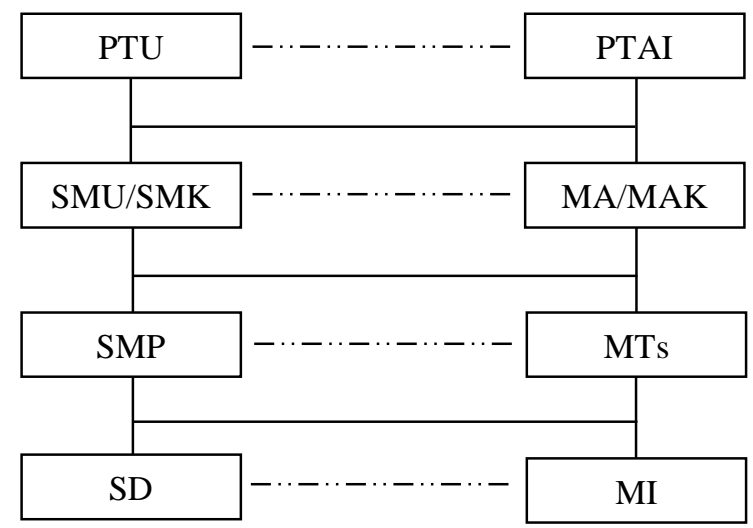

Keterangan:

$-=$ Garis melanjutkan

$-\cdot \cdot \cdot \cdot=$ Garis Kesetaraan dan Garis Pindah

Hasil dari peningkatan civil effect ijazah madrasah adalah sama dengan ijazah umum, seperti tertera dalam Bab II Pasal 2 SKB tiga menteri tersebut. Hakikat dari SKB tiga menteri tersebut adalah 1) Ijazah madrasah mempunyai nilai yang sama dengan ijazah sekolah umum yang setingkat/sederajat; 2) Lulusan madrasah dapat melanjutkan ke sekolah umum setingkat atas; 3) siswa madrasah dapat berpindah ke sekolah umum yang setingkat. Sebelum lahirnya SKB Tiga Menteri tahun 1975 tersebut, terdapat perbedaan mendasar antara lulusan madrasah dengan sekolah umum. Perbedaan mendasar ini terlihat sekali di dalam dua hal.
Pertama, kesempatan untuk melakukan studi lanjut. Lulusan madrasah pasca SKB dapat melanjutkan studi ke PT manapun, baik PTAI maupun PTU. Bagi lulusan madrasah pada kelompok ilmu eksakta (fisika dan Biologi) dapat melanjutkan ke Fakultas Kedokteran, Pertanian, Teknik, dan ilmu Pasti Alam. Sedangkan lulusan madrasah pad ailmu sosial dan humaniora dapat melanjutkan studinya ke Fakultas Hukum, Filsafat, bahasa, sastra, ekonomi, politik, dan sebagainya. Kesempatan melanjutkan studi adalah salah satu bagian dan pemerataan pendidikan. Josep D. Farrell (1982:45-46) mengemukakan bahwa salah satu masalah yang dihadapi negara-negara berkembang adalah pemerataan kesempatan melanjutkan pendidikan. Banyak anak-anak di negara berkembang tidak dapat menlanjutkan pendidikan ke lembaga yang lebih tinggi bahkan banyak pula yang drop out.

Kedua, kesempatan kerja. Sebelum lahirnya SKB Tiga Manteri kesempatan untuk menjadi pegawai negeri maupun swasta, bagi alumnus madrasah hanya terbatas dalam lingkungan Departemen Agama atau lembaga-lembaga keagamaan saja. Dengan SKB Tiga Manteri ini kesempatan itu lebih luas. Dengan diperluasnya kesempatan kerja di instansiinstansi pemerintahan (sipil dan militer) bagi alumni madrasah, maka alumni madrasah mempunyai kedudukan, kesempatan, dan peluang yang sama dengan alumni dari SMA. Hal ini menjadikan kesempatan prospek kerja alumni madrasah semakin luas, sehingga tingkat motivasi, proses, dan etos belajar siswa di madrasah semakin meningkat. Hal ini sesuai dengan rumusan motivasi dan etos kerja seseorang (termasuk belajar) setara dengan tingkat pengharapan di masa yang akan datang.

Ketiga, kesetaraan institusi madrasah dengan sekolah dalam hal pengelolaan, akses, dan pengembangan. Dari sudut ini, 
kelahiran SKB Tiga menteri itu dapat dilihat sebagai upaya untuk meminimalisir ekskapansi (kesenjangan) antara lulusan madrasah dengan sekolah umum. Upaya meminimalisir kesenjangan tersebut sangat diperlukan dalam rangka untuk menghilangkan dua pola pikir generasi Indonesia masa mendatang. Sebelum lahirnya SKB Tiga Menteri, madrasah masih didudukkan sebagai institusi pendidikan yang swadana dan dikelola oleh masyarakat (atau swasta) yang menerapkan kurikulum sendiri (yang terkadang tidak sesuai dengan standar yang ditetapkan oleh pemerintah). Oleh karena itu, standar lulusan madrasah tidak setara atau tidak diakui oleh pemerintah. Dengan keluarnya SKB Tiga Menteri, terlebih dengan peraturan yang menekankan keharusan madrasah untuk menerapkan Standar Nasional Pendidikan (SNP), dengan tetap mempertahankan ciri khasnya, maka alumni madrasah dapat setara dengan alumni SMU, karena mengacu pada SNP yang sama, sistem dan proses yang sama, serta sistem evaluasi yang sama pula.

Apabila dianalisis secara mendalam lagi, maka pada hakikatnya Madrasah pasca-SKB Tiga Menteri itu tiada lain adalah sekolah umum plus. Pada tingkat dasar, yaitu Madrasah Ibtidaiyah, sama dengan SD Plus; di tingkat SLTP, yaitu Madrasah Tsanawiyah, sama dengan SMP; dan tingkat SLTA, yaitu Madrasah Aliyah sama dengan SMA Plus. Plusnya di sini adalah sistem pendidikan yang didasarkan pada sistem yang "Islamu" serta mendapatkan mata pelajaran agama lebih banyak, yang tidak mungkin dapat diperoleh meraka apabila mereka memasuki sekolah umum. ${ }^{10}$

Sekalipun demikian, dari segi teknis opersional SKB Tiga Menteri ini bukalah tanpa problem. Terdapat sejumlah problem mendasar ditinjau dari segi

${ }^{10}$ Daulay, Haidar Putra. 2007. Sejarah Pertumbuhan dan Pembaruan Pendidikan Islam di implementasinya, yakni meliputi tenaga pengajar, sarana dan fasilitas, waktu pembelajaran, dan pendanaan. Komposisi kurikulum madrasah $70 \%$ adalah mata pelajaran umum dan $30 \%$ pelajaran agama menambah beban siswa madrasah. Di sisi lain $30 \%$ pelajaran agama termasuk bahasa Arab tidak mencukupi lulusan madrasah menjadi calon ulama. Menurut Husni Rahim, "Perlakuan diskriminatif tetap dirasakan ketika lulusan madrasah melanjutkan ke perguruan tinggi atau dunia kerja".

\section{Sistem Pendidikan Nasional dalam Undang-Undang No 2 Tahun 1989}

Pada tahun 1989, Pemerintah Indonesia mengeluarkan Undang-Undang Sistem Pendidikan Nasional (UU Sisdiknas) kembali. Produknya adalah Undang-Undang Nomor 2 tahun 1989 tentang Sistem Pendidikan Nasional (Sisdiknas). Undang-Undang ini terdiri dari XX Bab dan 59 Pasal; berisikan: Ketentan Umum, dasar fungsi dan tujuan, hak warga negara untuk memperoleh pendidikan, satuan jalur dan jenis pendidikan, jenjang pendidikan, peserta didik, tenaga kependidikan, sumber daya pendidikan, kurikulum, hari belajar dan libur, sekolah, bahasa pengantar, penilaian, peran serta masyarakat, badan pertimbangan pendidikan nasional, pengolahan, pengawasan, ketentuan lain, ketentuan pidana, ketentuan peralihan, ketentuan penutup.

Pada periode ini madrasah telah berada di bawah aturan Undang-Undang Sistem Pendidikan Nasional (UU Sisdiknas). Dalam UU Sisdiknas ini, dalam Bab II Pasal 4, tujuan pendidikan dirumuskan sebagai berikut, "Pendidikan Nasional bertujuan mencerdaskan kehidupan bangsa dan mengembangkan manusia Indonesia seutuhnya, yaitu

Indonesia. Jakarta: Kencana Prenada Media Group. hlm. 105

10 | Rausyan Fikr. Vol. 14 No. 1 Maret 2018. ISSN. 1979-0074 e-ISSN. 9772580594187 
manusia yang beriman dan bertakwa terhadap Tuhan Yang Maha Esa dan berbudi pekerti luhur, memiliki pengetahuan dan keterampilan, kesehatan jasmani dan ruhani, kepribadian yang mantap dan mandiri serta tanggung jawab kemasyarakatan dan kebangsaan.

Sejak diundangkannya UU No. 2 Tahun 1989 Undang-Undang tentang Sistem Pendidikan Nasional, ditindaklajuti dengan lahirnya Peraturan Pemerintah yang berkenaan dengan pendidikan meliputi:
a. PP No. 27 Tahun 1990 tentang Pendidikan Prasekolah
b. PP No. 28 Tahun 1990 tentang Pendidikan Dasar
c. PP No. 29 Tahun 1990 tentang Pendidikan Menengah
d. PP No. 30 Tahun 1990 yang kemudian tentang Pendidikan Tinggi diganti dengan PP No. 60 Tahun 1990
e. PP No. 72 Tahun 1991 tentang Pendidikan Luar Biasa
f. PP No. 73 Tahun 1991 tentang Pendidikan Luar Sekolah
g. PP No. 38 Tahun 1992 tentang Kependidikan

h. PP No. 39 Tahun 1992 tentang Peran serta Masyarakat dalam Pendidikan.

Peraturan Pemerintah yang terkait dengan sekolah dan madrasah adalah PP Nomor 28 dan 29 Tahun 1990. Di dalam PP No. 28 Tahun 1990 disebutkan pada Bab III Pasal 4 Ayat (3) dijelaskan bahwa sekolah dasar dan sekolah lanjutan tingkat pertama yang berciri khas agama Islam yang diselenggarakan Departemen Agama masing-masing disebut Madrasah Ibtidaiyah dan Madrasah Tsanawiyah.

Sedangkan PP Nomor 29 Tahun 1990

Bab I Pasal 1 membagi pendidikan menengah kepada: Pendidikan menengah kepada: Pendidikan Menengah Umum, Pendidikan Menengah Kejuruan, Pendidikan Menengah Keagamaan, Pendidikan Menengah Kedinasan, dan Pendidikan Menengah Luar biasa. Untuk menindaklanjuti pelaksanaan Peraturan Pemerintah Nomor 29 Tahun 1990 tersebut, Menteri Pendidikan dan Kebudayaan serta Menteri Agama masing-masing mengeluarkan Surat Keputusan. Menteri P dan K mengeluarkan Surat Keputusan No. 489/U/1992 tentang Sekolah Menengah Umum, sedangkan Menteri Agama mengeluarkan SK No. 370 Tahun 1993 tentang Madrasah Aliyah. Selanjutnya, Menteri Agama mengeluarkan Surat Keputusan No. 373 Tahun 1993 (tertanggal 22 Desember 1993) tentang Kurikulum Madrasah Aliyah (MA) dan Surat Keputusan No 374 Tahun 1993 (tertanggal 22 Desember 1993) tentang Kurikulum Madrasah Aliyah Keagamaan (MAK).

Berdasarkan Peraturan Pemerintah No. 28 dan 29 serta diikuti oleh Surat Keputusan Menteri Pendidikan dan Kebudayaan dan Meteri Agama dapat diketahui bahwa Madrasah adalah sekolah yang berciri khas agama Islam. Berkenaan dengan ini, maka madrasah Ibtidaiyah, Madrasah Tsanawiyah, dan Madrasah Aliyah memiliki kurikulum yang sama dengan sekolah umum (SD, SMP, SMA), ditambah dengan ciri keisalaman yang tertuang dalam kurikulum, yaitu memiliki mata pelajaran agama yang lebih dari sekolah. Sesuai dengan PP Nomor 29 yang membagi pendidikan menengah kepada beberapa jenis, maka madrasah pun dibagi pada dua jenis, yakni 1) Madrasah Aliyah yang setara dengan SMU, mengajarkan kurikulum SMU ditambah dengan mata pelajaran yang bercirikan Islam. Oleh karena itu, seluruh sistem madrasah Aliyah tersebut sama dengan sekolah umum. Hak dan civil effect-nya juga sama. 2) Madrasah Aliyah keagamaan; madrasah ini didasarkan pada PP No. 29 Tahun 1990, Bab I, Pasal I Ayat 2, yakni pendidikan pada jenjang menengah yang mengutamakan penguasaan pengetahuan khusus siswa tentang ajaran agama yang bersangkutan. 
Madrasah Aliyah jenis pertama, sesuai dengan Keputusan Menteri Agama (KMA) No. 370 Tahun 1993 di atas, adalah dikelompokkan kepada pendidikan menengah umum. Oleh karena itu, Madrasah Aliyah haruslah sejalan dengan pendidikan mengenah umum lainnya, hanya saja diberikan ciri khas, yakni menjadi sekolah menengah yang berciri khas agama Islam. Ciri khas ini tergambar dalam kurikulumnya yang ditampilkan dengan mata pelajaran keislaman, di samping struktur kurikulum seperti yang ada dalam kurikulum SMU. Dengan demikian tujuan isntitusional Madrasah Aliyah (MA) tersebut ada dua, yakni 1) perluasan pengetahuan dan peningkatan keterampilan siswa serta 2) penanaman nilai-nilai keislaman. Namun, penerapan 100 persen kurikulum sekolah berakibat siswa madrasah dibebani lebih berat dibanding sekolah umum padahal fasilitas belajar lebih buruk, maka kualitas lulusan madrasah pun tidak maksimal dan serba tanggung.

Sedangkan Madrasah Aliyah jenis kedua, yakni MAK, dapat digolongkan kepada sekolah menengah keagamaan. Menurut UU No. 2 Tahun 1989, Bab IV, Pasal 11 Ayat (6) disebutkan bahwa Pendidikan Menengah Keagamaan merupakan pendidikan yang mempersiapkan peserta didik untuk dapat menjalankan peranan yang menuntut penguasaan pengetahuan khusus tentang ajaran agama yang bersangkutan.

\section{Sistem Pendidikan Nasional dalam Undang-Undang No. 20 Tahun 2003}

Krisis multidimensi yang melanda Indonesia sejak 1997/1998, salah satunya, menunjukkan kegagalan hasil pendidikan di Indonesia. Krisis ekonomi, krisis politik, krisis budaya, dan krisi moral, salah satunya berakar dari kegagalan pendidikan tersebut. Oleh karena itu, krisis multidimensi ini telah mendorong Pemerintah dan Rakyat
Indonesia untuk mengkaji ulang kembali landasan pendidikan. Hasilnya adalah lahirnya Undang-Undang Nomor 20 Tahun 2003 tentang Sistem Pendidikan Nasional.

Menurut A. Tafsir (2008a:151), UU No. 20 tahun 2003 ini kembali memberikan tekanan pada pendidikan Keimanan, ketakwaan, dan moral-agama (atau pendidikan pengembangan hati). Pasal 3 UU No. 20/2003 merumuskan tujuan pendidikan Nasional sebagai berikut, "Pendidikan Nasional bertujuan untuk berkembangnya potensi peserta didik agar menjadi manusia yang beriman dan bertakwa kepada Tuhan Yang Maha Esa, berakhlak mulia, sehat, berilmu, cakap, kreatif, mandiri, dan menjadi warga negara yang demokratis serta bertanggung jawab". Dalam Pasal 4 ayat (1) juga ditegaskan, "Pendidikan diselenggarakan secara demokratis dan berkeadilan serta tidak diskriminatif dengan menjunjung tinggi hak asasi manusia, nilai-nilai keagamaan, nilai kultural, dan kemajemukan bangsa.

Pendidikan yang mengarah pada substansi pendidikan keimanan dan ketakwaan mendapat tekanan yang cukup kuat. Pasal 36 ayat (3.a) pada UU No. 20/2003 ini disebutkan bahwa kurikulum disusun dengan memperhatikan peningkatan iman dan takwa. Sedangkan pada pasal 37 ayat (1.a) disebutkan bahwa "Pendidikan agama wajib ada di dalam kurikulum pendidikan dasar dan menengah". Sedangkan dalam pasal 37 ayat (2.a) dinyatakan bahwa "Pendidikan agama wajib ada di dalam kurikulum pendidikan tinggi". Berdasarkan beberapa butir UU di atas, jelas bahwa UU telah menjamin terwujudnya peserta didik yang beriman dan bertakwa sebagaimana dituntut dalam rumusan tujuan pendidikan.

Fungsi, peranan, dan status madrasah secara substansial pada Undang-Undang No. 20 Tahun 2003 ini tidak berbeda dengan madrasah pada Undang-Undang No. 2 Tahun 1989. Hanya saja dilihat dari 
kekuatan yuridisnya, madrasah pada Undang-Undang No. 20 Tahun 2003 lebih kuat dan lebih kokoh, karena penyebutan nomenklatur madrasah masuk pada batang tubuh undang-undang. Hal ini berbeda denga UU No.2 tahun 1989, peristilahan madrasah hanya berada dalam Peraturan Pemerintah dan Surat Keputusan Menteri. Madrasah Ibtidaiyah dan Madrasah Tsanawiyah dijelaskan pada PP No. 28 Tahun 1990. Sedangkan kata Madrasah Aliyah disebutkan pada Surat Keputusan Menteri Pendidikan dan Kebudayaan No. 489/U/1992.

Penyebutan madrasah pada UndangUndang No. 20 Tahun 2003 dapat ditemukan pada pasal 17 dan 18.

a. Pasal 17: Pendidikan Dasar berbentuk Sekolah Dasar (SD) dan Madrasah Ibtidaiyah (MI) atau bentuk lain yang sederajat serta Sekolah Menengah Pertama (SMP) dan Madrasah Tsanawiyah atau bentuk lain yang sederajat.

b. Pasal 18: Pendidikan Menengah berbentuk Sekolah Menengah Atas (SMA), Madrasah Aliyah (MA), Sekolah Menengah Kejuruan (SMK), dan Madrasah Aliyah Kejuruan (MAK) atau bentuk lain yang sederajat.

UU Sisdiknas No. 20/2003 sebenarnya semakin mengurangi ketimpangan yang ada dengan memasukkan pendidikan keagamaan dalam bagian tersendiri, namun demikian tetap sulit meningkatkan citra madrasah menjadi lebih tinggi. "Sampai sekarang diskriminasi tetap terjadi, termasuk perhatian Pemda-pemda yang masih kurang, misalnya Pemda Jawa Barat yang hanya memberi tunjangan kepada guru sekolah agama Rp 750 ribu (per-tahun), sementara guru sekolah umum diberi tunjangan Rp 1 juta.

\section{E. Dari Dikotomi Menuju Konvergensi}

Berdasarkan pada Undang-Undang dasar 1945 pasal 31 ayat (3) Pemerintah berkewajiban untuk menyelenggarakan satu sistem pendidikan formal. Namun pada kenyataannya, Namun, dalam UU Sisdiknas, terkahir UU Nomor 20 tahun 2003 menyebut dua buah institusi pendidikan yakni sekolah dan Madrasah. Keduanya diakui sebagai institusi pendidikan dalam sistem pendidikan Nasional di Indonesia. Akomodasi negara terhadap keberadaan madrasah (dari mulai madrasah Ibtida'iyah hingga 'Aliyah, serta Perguruan Tinggi Agama Islam), adalah tidak salah, jika dianggap sebagai kemenangan politik pendidikan bagi umat Islam. Indikator terhadap hal ini adalah tidak atau belum adanya institusi pendidikan non-Islam yang diselenggarakan dan dikelola oleh pemerintah.

Pada satu sisi terdapat sekolahsekolah yang dikelola oleh Diknas, pada sisi lain terdapat sekolah-sekolah yang dikelola oleh Depag. Dari kedua sekolah ini, muncul persepsi bahwa sekolah-sekolah yang dikelola Diknas dikesani sebagai sekolah "umum", non-agamis, atau "sekuler", tapi maju, terdepan, dan modern. Sedangkan, sekolah-sekolah yang dikelola Departemen Agama, dikesani sebagai sekolah "agama" dan religius, tetapi tertinggal, tertutup bagi kemajuan Ipteks, dan tradisional. Mungkin persepsi tersebut tidak sepenuhnya benar, dan juga tidak sepenuhnya salah. Di satu sisi, terdapat sekolah-sekolah yang dikelola Diknas yang masih tertinggal, tradisional, dan kumuh; dan di sisi lain, terdapat sekolah-sekolah Islam yang modern, berstandar internasional, dan maju. Dikotomi tersebut memang masih belum dapat dihapuskan, tetapi perlu untuk dimediasi dan dikonvergensikan, agar agama dan ipteks diajarkan, dikuasai, dan diaplikasikan oleh setiap peserta didik.

Pandangan dikotomis mentipologikan kehidupan secara sederhana, yakni berpasang-pasangan dan atau berlawanlawanan, atau sejalan dengan kerangkan 
berpikir Newtonian tentang binary oposition (oposisi biner). Dikotomi dan dualisme sistem pendidikan Islam yang ada di Indonesia, dan lainnya, seperti di atas salah satunya bermuara dari pandangan dikotomik tentang kehidupan (yakni dunia dan akherat), struktur manusia (jasmani dan rohani), serta ilmu (agama dan "umum". Dari dikotomi-dikotomi tersebut, maka dualisme sistem pendidikan di Indonesia pun tumbuh berkembang. Pendidikan Islam diposisikan pada aspek akhirat, rohani, dan agama saja, sementara pendidikan umum diposisikan pada aspek duniawi, jasmani, dan sains (ipteks). Dengan demikian, pendidikan keagamaan dihadapkan dengan pendidikan non-keagamaan, pendidikan keislaman dengan non-keislaman, pendidikan agama dengan pendidikan umum, demikian seterusnya. Selebihnya, pendidikan (agama) Islam seolah-olah hanya mengurusi persoalan ritual dan spiritual, sementara kehidupan sain, teknologi, sosial, budaya, ekonomi, politik, dan seni dianggap sebagai urusan duniawi yang menjadi bidang garapan pendidikan non-agama atau "umum".

Adanya perubahan dan atau penyempitan pengertian ulama dan fuqaha, sebagai orang-orang yang hanya mengerti persoalan-persoalan doktrin, hukum islam, dan teks-teks klasik, sehingga tidak dimasukkan dalam barisan kaum intelektual, merupakan salah satu implikasi dari pandangan dikotomis tersebut. Menurut Azyumardi Azra (1999), pemahaman semacam itu muncul ketika umat Islam Indonesia mengalami keterbelakangan dan disintegrasi dalam berbagai aspek kehidupan masyarakat. Perbenturan umat Islam dengan pendidikan dan kemajuan Barat memunculkan kaum intelektual baru (cendikiawan sekuler), yang menurut Benda (dalam Sartono Kartodirjo, ed. 1981) sebagian besar intelektual tersebut merupakan hasil pendidikan Barat yang terlatih berpikir secara Barat. Dalam proses pendidikannya, mereka mengalami brain washing (cuci otak), sehingga mereka menjadi teralienasi (terasing) dari ajaran-ajaran Islam dan Muslim sendiri. Bahkan terjadi gap antara kaum intelektual baru (sekuler) dengan intelektual lama (ulama), dan ulama dikonotasikan sebagai kaum santri atau kaum sarungan yang hanya mengerti soalsoal keagamaan dan buta dalam masalahmasalah keduniaan.

Paradigma dikotomis mempunyai implikasi terhadap pengembangan pendidikan di Indonesia, pendidikan agama Islam lebih diorientasikan pada keakhiratan, sedangkan masalah duniawi dianggap tidak penting, serta menekankan ada pendalaman al-'ulum al-diniyyah (ilmu-ilmu keagamaan) yang merupakan jalan pintas untuk menuju kebahagiaan akhirat. Sementara, sains (ipteks) dianggap terpisah dari agama, yang diorientasikan pada urusan keduniawiaan, serta menekankan pada pendalaman al-'ulum aldunyawiyyah (ilmu-ilmu keduniaan). Dari segi pendekatan, dari kedua pendidikan ini, secara dikotomis, dapat dibedakan. Pendidikan (agama) Islam bersifat normatif, doktriner, dan absolut. Peserta didik diarahkan untuk menjadi pelaku (actor) yang loyal (setia), memiliki sikap commitment (keberpihakan), dan dedikasi (pengabdian) yang tinggi terhadap agama yang dipelajarinya. Sementara itu, kajiankajian keilmuan yang bersifat empiris, rasional, dan analitis kritis merupakan karakteristik dari pendidikan ilmu "umum".

\begin{tabular}{|l|l|l||}
\hline \multicolumn{1}{|c|}{ UNSUR } & \multicolumn{1}{|c|}{ SEKOLAH } & \multicolumn{1}{c|}{ MADRASAH } \\
\hline $\begin{array}{l}\text { Penyelenggara/ } \\
\text { Pengelola }\end{array}$ & $\begin{array}{l}\text { Pemerintah dan } \\
\text { Masyarakat }\end{array}$ & $\begin{array}{l}\text { Pemerintah } \\
\text { Masyarakat }\end{array}$ \\
\hline Kurikulum & $\begin{array}{l}\text { Kurikulum } \\
\text { Sentralistik } \\
\text { Pemerintah } \\
\text { (Mata pelajaran } \\
\text { umum) }\end{array}$ & $\begin{array}{l}\text { Kurikulum } \\
\text { Terintegrasi (Mata } \\
\text { Pelajaran Umum dan } \\
\text { Agama Islam) }\end{array}$ \\
\hline Paradigma & Sekuler & Integrasi-Spasial \\
\hline Tujuan Umum & $\begin{array}{l}\text { Pengembangan } \\
\text { Fisik dan Akal }\end{array}$ & $\begin{array}{l}\text { Pengembangan Fisik, } \\
\text { Akal, dan Hati }\end{array}$ \\
\hline
\end{tabular}




\begin{tabular}{||l|l|l||}
\hline Tujuan Khusus & $\begin{array}{l}\text { Lulusan yang } \\
\text { unggul, } \\
\text { kompetitif, dan } \\
\text { profesional }\end{array}$ & $\begin{array}{l}\text { Mencipatakan } \\
\text { lulusan yang unggul } \\
\text { dan kompetitif } \\
\text { (menguasai ilmu } \\
\text { keislaman, sain } \\
\text { modern, dan } \\
\text { teknologi) dan } \\
\text { berakhlakul karimah }\end{array}$ \\
\hline $\begin{array}{l}\text { Sistem } \\
\text { Pembelajaran }\end{array}$ & $\begin{array}{l}\text { Empiris, } \\
\text { rasional, dan } \\
\text { analisis kritis }\end{array}$ & $\begin{array}{l}\text { Normatif, doktriner, } \\
\text { dan absolut }\end{array}$ \\
\hline $\begin{array}{l}\text { Materi } \\
\text { Pembelajaran }\end{array}$ & $\begin{array}{l}\text { Orientasi Skill } \\
\text { dan Substansi }\end{array}$ & $\begin{array}{l}\text { Orientasi subsatansi, } \\
\text { skill, dan teks }\end{array}$ \\
\hline
\end{tabular}

Dikotomi dan konsekuensinya, sebenarnya, bukan hanya terjadi di Indonesia saja dan pada masa sekarang saja. Secara doktrinal, ajaran Islam tidak mengenal perbedaan antara ilmu agama dan ilmu dunia. Namun dalam realitasnya, dalam sejarah Islam abad pertengahan, dikotomi ini terjadi, di mana ulum aldiniyyah (penekanan pada tafsir, hadits, fiqh, dan tasawuf) meng"hegemoni" atau dan mengontrol sains, teknologi, serta perkembangan madrasah dan al-jami'ah. Misalnya, keberadaan madrasah al-thib (sekolah kedokteran) tidak dan dapat mengembangkan ilmu kedokteran dengan bebas, karena sering digugat fuqaha. Para saintis muslim pernah digugat oleh para fuqaha dan tidak diperkenan menggunakan organ-oragan mayat sekalipun dibedah untuk diselidiki. Demikian pula, Rumah Sakit Riset di Baghdad dan Kairo, karena dibayangi legalisme fiqh yang kaku, akhirnya harus berkonsentrasi pada ilmu kedokteran teoritis dan perawatan.

Mengapa legalisme fiqh atau syari'ah dan atau ortodoksi agama serta semangat intoleransi terhadap para saintis (kalangan muslim dan non-muslim) begitu dominan dalam lembaga pendidikan, temasuk di Indonesia? Menurut Azyumardi Azra (1994), hal itu terjadi karena: 1) Pandangan tentang ketinggian syari'ah atau ilmu-ilmu keagamaan, sebagai "jalan tol" untuk menuju Tuhan; 2) lembaga-lembaga pendidikan Islam secara institusional dikuasai oleh mereka yang ahli dalam bidang-bidang keagamaan, sehingga kelompok saintis (dar al-'ilm) tidak mendapat dukungan secara institusional, sehingga kaum saintis tidak berdaya menghadapi fuqaha yang mengklaim legitimasi realigius sebagai the guardian of God's given law (pelindung/penguasa syari'ah); dan 3) hampir seluruh madrasah/ al-Jami'ah didirikan dan dipertahankan dengan dana wakaf dari para dermawan dan penguasa politik muslim. Motivasi kesalehan mendorong para dermawan untuk mengarahkan madrasah pada lapanganlapangan ilmu-ilmu agama yang lebih banyak mendatangkan pahala, sementara itu penguasa politik yang memperkarsai berdirinya madrasah, mungkin karena dorongan politik tertentu atau motivasi murni untuk menegakkan ortodoksi Sunni, serta mendikte madrasah/ al-Jami'ah untuk tetap dalam kerangka ortodoksi (kerangka syari'ah).

Sejarah membuktikan bahwa dikotomi ekstrem, yang menempatkan hegemoni ortodoksi (syari'ah) di atas ipteks dan ipteks berada pada posisi marginal, telah menyebabkan kemunduran peradaban sebuah agama atau bangsa. Hal ini terjadi pada bangsa Eropa pada masa The Dark Middle Age dan pada peradaban Muslim. Sebaliknya, penyampingan agama atas ipteks telah menyebabkan sekulerisasi tanpa kontrol, ekploitasi alam yang tidak terkendali, dan dekadensi moral yang belum teratasi. Isue-isue politik gnocida (pembunuhan masal), aparthaed (racial cleansing), global warming, climate change, dan peningkatan stress, depresi, serta suicide (bunuh diri), merupakan salah satu dampak dari terpinggirkannya peran agama dalam perkembangan ipteks.

Oleh karena itu, berbagai upaya yang dilakukan oleh para pembaharu Muslim, termasuk dalam dunia pendidikan, untuk kembali menyeimbangkan dan menyinergikan antara agama dan ipteks, mutlak dilakukan sebagai terobosan dari 
krisis multidimensi yang melanda kemanusiaan. Penguatan pendidikan (agama) Islam dalam pendidikan nasional di Indonesia, mutlak harus terus diarusutamakan, terutama ketika kegagalan pendidikan Agama (Islam) dituding sebagai salah faktor utama dari kegagalam moral di Indonesia. ${ }^{11}$ Upaya Islamisasi pengetahuan (dalam artian memadukan nilai-nilai keislaman dalam ipteks) dan "wahyu memandu ilmu" merupakan salah satu upaya ke arah tersebut. Dalam UU Nomor 20 Tahun 2003 pasal 37 ayat (1) disebutkan bahwa "Pendidikan agama dimaksudkan untuk membentuk peserta didik menjadi manusia beriman dan bertakwa kepada Tuhan Yang Maha Esa serta berakhlak mulia". Hal ini berarti bahwa pendidikan agama kembali mendapat tekanan dan posisi yang kuat dalam sistem pendidikan di Indonesia.

Terdapat hal yang penting untuk dicatat bahwa yang diperlukan sekarang dalam upaya perbaikan mutu pendidikan formal adalah memperbaiki kualitas sistemnya. Jika umat Islam menghendaki adanya sistem pendidikan yang Islami (berlandaskan pada tata nilai keislaman), bukanlah hanya terletak pada keberadaan bidang studi (mata pelajaran) agama yang banyak saja, sebagaimana terjadi pada madrasah pada masa lalu, tetapi haruslah diorientasikan untuk membangun sistem yang islami. Dalam hal ini, yang dimaksud dengan sistem yakni seperangkat perencanaan, proses, dan eavaluasi pendidikan yang dibangun di atas tata nilai Islami. Hal ini ditempuh dengan upaya penciptaan suasana religius Islami di setiap

\footnotetext{
${ }^{11}$ Kegagalan pendidikan agama di sekolah telah diungkapoleh banyak kalangan, misalnya oleh Azyumardi Azra (2003) dan A. Tafsir (2008:123). Namun, Azyumardi Azra menyangkal kalau kegagalan Pendidikan Agama sebagai faktor dari tingginya angka korupsi di Inodnesia. Azyumardi menyebutkan bahwa hasil survey International Country Risk Guide Index (ICRGI) sejak tahun 1992 sampai 2000 menunjukkan bahwa agama negara
}

lingkungan pendidikan, baik pendidikan formal, non-formal, dan informal (Muhaimin, 2009: 55-59).

\section{F. Penutup}

Dikotomi antara Ilmu "agama" dan ilmu "umum" telah melahirkan dualitas pada sistem pendidikan formal di Indonesia, yakni sekolah dan madrasah. Sekolah dipersepsi sebagai "institusi pendidikan yang menyelenggarakan pendidikan ilmu umum", yang diselenggarakan dan dikelola oleh Departemen Pendidikan Nasional. Sedangkan madrasah dipersepsi sebagai "institusi yang menyelenggarakan pendidikan ilmu agama" yang diselenggarakan dan dikelola oleh Kemenag.

Dari kedua sekolah ini, muncul persepsi bahwa sekolah-sekolah yang dikelola Diknas dikesani sebagai sekolah "umum", non-agamis, atau "sekuler", tapi maju, terdepan, dan modern. Sedangkan, sekolah-sekolah yang dikelola Departemen Agama, dikesani sebagai sekolah "agama" dan religius, tetapi tertinggal, tertutup bagi kemajuan Ipteks, dan tradisional. Mungkin persepsi tersebut tidak sepenuhnya benar, dan juga tidak sepenuhnya salah. Di satu sisi, terdapat sekolah-sekolah yang dikelola Diknas yang masih tertinggal, tradisional, dan kumuh; dan di sisi lain, terdapat sekolah-sekolah Islam yang modern, berstandar internasional, dan maju. Dikotomi tersebut memang masih belum dapat dihapuskan, tetapi perlu untuk dimediasi dan dikonvergensikan, agar agama dan ipteks diajarkan, dikuasai, dan diaplikasikan oleh setiap peserta didik.

atau mayoritas penduduk beragama tertentu tidak identik dengan korupsi. Satu sisi terdapat negaranegara berpenduduk agama Islam, Kristen, dan Hindu/Budha yang memiliki indeks persepsi korupsi (IPK) nya di atas 7 (tinggi), seperti Indonesia $(9,25)$, Bangladesh, Filipina, Thailan, Rusia, dan Meksiko. Tetapi di sisi lain, terdapat negara berpenduduk agama tertentu dengan IPK rendah, seperti Iran, Arab Saudi, Inggris, Kanada, AS, dan Syiria. 
Tataran konsep dikotomi akan menimbulkan dulaisme pendidikan pada tataran praksis yang pada berikutnya akan menimbulkan keterpurukan hasil dalam pendidikan. Yang penting untuk dicatat bahwa yang diperlukan sekarang dalam upaya perbaikan mutu pendidikan formal adalah memperbaiki kualitas sistemnya. Dalam hal ini, yang dimaksud dengan sistem yakni seperangkat perencanaan, proses, dan eavaluasi pendidikan yang dibangun di atas tata nilai Islami.

\section{DAFTAR PUSTAKA}

Ahmad Watik Pratiknya, "Identifikasi Masalah Pendidikan Agama Islam di Indonesia", Muslih Usa (Ed.), Pendidikan Islam di Indonesia Antara Cita dan Fakta Yogyakarta : Tiara Wacana, 1991.

Ahmad Tafsir, Ilmu Pendidikan dalam Perspektif Islam, Bandung, Remaja Rosda Karya, 2007, cet-7

Azra, Azyumardi. "Islamic Thought: Theory, Concept, and Doctrines in the Context of Southeast Asia". Dalam KS Nathan dan HM Kamali. Islam in Southeats Asia for the 21 th Century. Singapore: ISEAS. 2005.

Azyumardi Azra, dalam Marwan Saridjo, Bunga Rampai Pendidikan Agama Islam, Amissco, Jakarta, 1996.

Abudin Nata, Manajemen Pendidikan, Mengatasi kelemahan pendidikan Islam di Indonesia, Jakarta: Kencana Prebada Media Group, 2008, Cet-3.

Ahmad Syafi'i Ma'arif, Pemikiran tentang Pembaharuan Pendidikan Islam di Azyumardi Azra, dalam Marwan Saridjo, Bunga Rampai Pendidikan Agama Islam, Amissco, Jakarta, 1996.
Daulay, Haidar Putra. Sejarah Pertumbuhan dan Pembaruan Pendidikan Islam di Indonesia. Jakarta: Kencana Prenada Media Group. 2007.

Daulay, Haidar Putra. Sejarah Pertumbuhan dan Pembaruan Pendidikan Islam di Indonesia. Jakarta: Kencana Prenada Media Group. 2007.

Departemen Pendidikan dan Kebudayaan, "Dulaisme", Kamus Besar Bahasa Indonesia Jakarta: Balai Pustaka, 1989

Departemen Agama RI, Al-Quran dan Terjemahan, J-Art. 2004

Departemen Pendidikan dan Kebudayaan, "Dulaisme", Kamus Besar Bahasa Indonesia Jakarta: Balai Pustaka, 1989.

Isma'il Raji al-Faruqi, Islamization of Knowledge: General Principles and Workplan Hemdon : HIT, 1982.

John M. Echols dan Hassan Shadily, Kamus Inggris-Indonesia Jakarta: PT. Gramedia Utama, 1992

Kawakib, A. Munir. Pesantren and Globalization. Malang: UIN Malang Press. 2009.

Steenbrink, Karel. Pesantren, Madrasah, Sekolah. Jakarta: LP3ES. 1985.

Zakiah Darajat, dalam buku "Peran Agama dalam Kesehatan Mental”, Jakarta, Gunung Agung, 1996,

Zakiah Darajat, dkk, Ilmu Pendidikan Islam, Jakarta, Bumi Aksara, 1992, cet-2.

Zakiah Darajat, Kesehatan Mental, Jakarta, Gunung Agung, 1996, cet-23 

Memahami Dikotomi dan Dualisme Pendidikan di Indonesia

1 | Rausyan Fikr. Vol. 14 No. 1 Maret 2018. ISSN. 1979-0074 e-ISSN. 9772580594187 

Memahami Dikotomi dan Dualisme Pendidikan di Indonesia

19 | Rausyan Fikr. Vol. 14 No. 1 Maret 2018. ISSN. 1979-0074 e-ISSN. 9772580594187 